\title{
COVID-19: An Overview of Economic Waves on Indian Economy
}

\section{OPEN ACCESS}

Manuscript ID:

ECO-2020-08033201

Volume: 8

Issue: 3

Month: June

Year: 2020

P-ISSN: 2319-961X

E-ISSN: 2582-0192

Received: 03.05.2020

Accepted: 20.05.2020

Published: 01.06.2020

Citation:

Jayaselvi, S. "COVID-19:

An Overview of Economic

Waves on Indian

Economy." Shanlax

International Journal of

Economics, vol. 8, no. 3, 2020, pp. 114-119.

DOI:

https://doi.org/10.34293/

economics.v8i3.3201

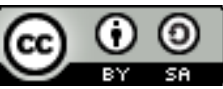

This work is licensed under a Creative Commons Attribution-ShareAlike 4.0 International License

\author{
S. Jayaselvi \\ Assistant Professor, Department of Management Studies \\ Amrita College of Engineering and Technology, Nagercoil, Tamil Nadu, India \\ (D) https://orcid.org/0000-0002-0828-3709
}

\begin{abstract}
A worldwide pandemic that has a powerful disruptive in the world is the COVID-19 outbreak. It brought significant volatility and chaos, which are affecting investors' confidence in Indian markets and the world. Most of the people lost their lives, resources, jobs, etc. As the whole countries in the world are struggling, the whole economy standstill, and it's very difficult to overcome from the recession. The Indian government took rapid decisions to prevent the disaster novel Coronavirus or Covid-19 by launching the complete nation-wide lockdown for 40 days. The impact of the forty days lockdown almost brought the economy into a standstill position. The economic growth goes into the negative figure. Even though some measures made by the government through monetary, fiscal, and economic policy still, the economy's needs are not fulfilled desirably. A great financial loss occurs in all sectors that lead to an increase the government debts and deficit financing in the economy. The experts suggested that the revival from this recession takes another two years. A significant monetary and liquidity measures taken by the Reserve Bank of India and fiscal measures by the government would alleviate the adverse impact on domestic demand and help spur economic activity once normalcy is restored. Therefore an innovative measure needs to revive the economy. The danger of the economy affects a lot than its health risks; therefore, the governments' concern needs to find the funds to fight COVID-19 and to keep the economy alive and augmentation.
\end{abstract}

Keywords: COVID-19, Lockdown, Economic impacts, Finance, Industry, Growth.

\section{Introduction}

A worldwide pandemic that has a powerful disruptive in the world is the COVID-19 outbreak. It brought significant volatility and chaos, which are affecting investors' confidence in Indian markets and the world. India is one of the emerging economies that hold the position of the fifth-largest economy by nominal GDP and third-largest by purchasing power parity (PPP), which has the second-largest population country in which the population size of about 1.3 billion after China in the world. COVID-19 emerged from China and started to spread all other countries rapidly and create a great impact on world countries. Most of the people lost their lives, resources, jobs, etc. As the whole countries in the world are struggling, the whole economy standstill, and it's very difficult to overcome from the recession. The Indian government took a rapid decision to prevent the disaster novel Coronavirus or Covid-19 by launching the complete nation-wide lockdown for 40 days. The result of 40 days lockdown is direct output loss of more than 8 percent over time. There are the indirect impacts on livelihoods of the unorganized workforce, and a sharp increase in corporate and banking stress, which are likely to further weigh on growth.

\section{COVID-19 \& Indian Economic Challenges}

Indian economic growth has been highly disruptive, and this has a great impact on various sectors of the economy. International Monetary Fund projection for India for the financial year 2021-22 of 1.9 percent Gross Domestic Product (GDP) growth is the highest among the G-20 nations. According to 
Acute Ratings, the Indian economy is expected to lose over $\$ 4.5$ billion every day due to the lockdown. Almost all business affected and Supply chain has been put under stress due to not movement of goods from one place to another. The unorganized sector workers and daily wage earners are the most at risk. The following figure illustrates the impact of COVID-19 among various sectors viz agriculture, industry, trade and commerce, supply chain, logistics, different markets, finance, and all economic activities.

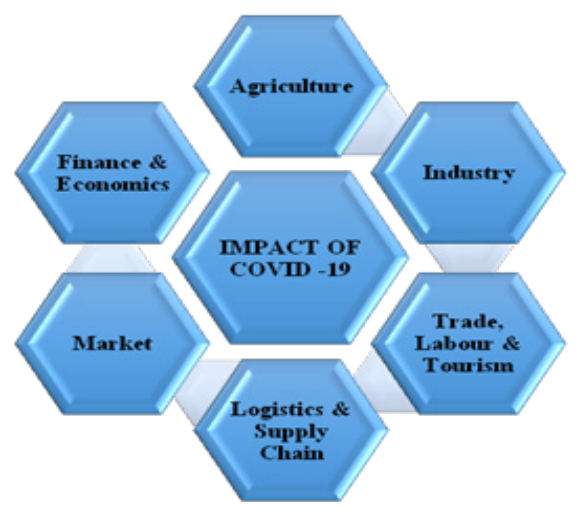

\section{Fig 1: Impact of Covid-19 on Various Sectors}

With COVID-19, the Indian economy is facing a major slowdown, which was visible over the recent quarters even before the crisis struck. In the third quarter of the current economic year, the economy grew at a six-year low rate of 4.7 percent. With all these problems damaged all the efforts of the world of work from multiple directions, companies are faced with a challenging status to sustain in this environment. They are forced to make tough decisions such as reducing salaries, giving pink slips to employees, and opting for various other costcutting measures. The outbreak has made troubles for the Indian workforce and especially for the daily wage earners and contractual workers.

The table and figure 2 represent the estimated impact on India by sector GVA between April \& June 2020. Gross Value Added (GVA) is a tool for the metric measure of economic productivity, which consists of a corporate subsidiary, company, or village to an economy, producer, sector, or region. And added that the number of goods and services that have been produced in a country, minus the cost of all inputs and raw materials that are straight attributable to that production.
Table 1: COVID-19: Estimated Impact on India between April \& June 2020 by sector GVA

\begin{tabular}{|l|c|}
\hline \multicolumn{1}{|c|}{ Sectors } & $\begin{array}{c}\text { Value in } \\
\text { Percentage }\end{array}$ \\
\hline $\begin{array}{l}\text { Financial, Real Estate \& Professional } \\
\text { Services }\end{array}$ & -17.3 \\
\hline Mining \& Quarrying & -14.7 \\
\hline $\begin{array}{l}\text { Electricity, gas, water supply \& other } \\
\text { utility services }\end{array}$ & -13.9 \\
\hline Construction & -13.3 \\
\hline $\begin{array}{l}\text { Trade, Hotels, transport, Communication } \\
\text { \& broadcasting services }\end{array}$ & -9.7 \\
\hline Manufacturing & -6.3 \\
\hline Agriculture, Forestry \&Fishing & -1.3 \\
\hline $\begin{array}{l}\text { Public Administration, Defence \& other } \\
\text { services }\end{array}$ & -0.4 \\
\hline
\end{tabular}

Source: Statista 2020

Fig. 2 COVID-19; Estimated Impact on India between April \& June 2020 by sector GVA

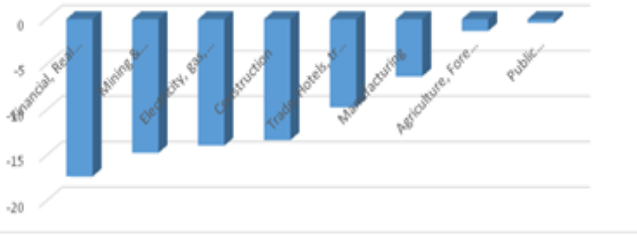

\section{Impacts on Agriculture}

India's economy is the rural economy, which covers a majority of nearly 69 percent. Indian agriculture is a remarkable one as it holds the position of the second rank globally in food and agricultural production, while agricultural shipping was $\$ 38.5$ billion. There are negative consequences of the COVID-19 pandemic on the farm economy. India's Green Revolution fame MS Swaminathan expressed that the country's rural economy is not inadequately planned for the pandemic. Further, he pointed out that the situation could be dealt with if the institutional infrastructure is mobilized. Vegetables are rotting in wholesale markets and farmers burning harvests for lack of logistics during the lockdown period. The Centre revealed a $\square 1.7$ lakh crore COVID-19 economic relief package, which includes direct cash transfers for farmers and a hike in MGNREGA wages. Luckily there is no immediate problem; we have sufficient food reserves in providing the food commodities as pledged in the National Food Security Act. Appreciable things 
have done by Indian farmers who transformed a 'ship to mouth' circumstances to a 'right to food' commitment.

\section{Impacts on Industries}

In India, rapid economic growth is possible with the efficient functioning of the industrial sector. India is the world's sixth-largest manufacturer, representing 3 percent of global manufacturing output and employs over 57 million people. The entire value chains of most major industries in India are disrupting and severely affected. The automotive industry is no different. The automobile industry is the world's fourth-largest by production that contributes 10 percent of India's GDP and has one of the world's fastest-growing e-commerce markets. Already it faces a great challenge for the impacts of Goods and Service Tax (GST) and demonetization. Also, that COVID-19 makes new adverse waves in this sector. The report released by Fitch Solutions depicts that vehicle product in India is likely to contract by 8.3 percent in 2020 following an estimated 13.2 percent decline in 2019. Many companies in India have deferred or significantly reduced operations. Young start-ups have been impacted by a lack of finance to invest. Even Amazon and Walmart owned Flip kart announced to sell only essential goods in India.

In India, Fast Moving Consumer goods have reduced operations expressively and are concentrating on essentials. The leading industry in India is the textile industry that contributes 7 percent of Industrial output and 2 percent of India's GDP while employs over 45 million people directly, which affects severely due to COVID-19. The toll on the pharmaceutical industry is of significant concern for India, mainly as 70 percent of active pharmaceutical ingredients (API) are imported from China. As COVID-19 is rapidly making its way through India, medication is going to be the number one consumer demand. Because there are not nearly enough APIs to manufacture medicines, the subsequent traders and the market are witnessing 'hit the roof prices.' The prices of vitamins and penicillin alone already realize a 50 percent surge.

India's telecommunication industry is the world's second-largest by several mobile phones, smartphones, and internet users. The IT industry is the emerging one that contributes to export with $\$ 180$ billion in revenue and provides employment opportunities to 4 million people. A significant slowdown in the growth of this sector found due to this recession. It is expected an adverse impact on the short term with lower growth of 3-5 percent in the current financial year. The report says that top software exporters, including TATA Consultancy Services, Infosys, and HCL Technologies, will be wedged most by the tapering technology spending from clients who are from US and Europe subsequent lockdowns across the globe.

\section{Impacts on Informal Sector}

As of 2019, the world's second-largest labor force is the Indian labor force, which consists of 520 million workers. Among them, the vast majority of the workers (94 percent) from informal sectors. These informal sector workers face a great challenge, and they lost their jobs in the lockdown period. There are 150 to 175 million workers engaged in the COVID -19 impacted segments like trade, transport, and hotels, construction, and manufacturing as the report of NSSO. Suddenly daily wage earners who are the Migrant workers lost their jobs and struggled for their bread due to the impact of COVID-19. Therefore large numbers of migrant workers started to go back to their hometown by walk because of the non-availability of transports facilities.

\section{Impacts on Trade \& Commerce}

India has been a member of the World Trade Organisation, which influences the world market. India's trade is highly influential as the data says it was the world's tenth-largest importer and the nineteenth largest exporter in 2019. Besides, it ranks 63rd on Ease of doing business index and 68th rank on the Global Competitive Report. COVID-19 ceases all the trading activities internally and externally.

\section{Impacts on Supply Chains and Logistics}

Supply Chain broke down completely because of the lockdown. Supply Chain disruptions in various sectors like pharmaceuticals, electronics, renewable energy, and automobiles where there is direct or indirect import dependence on affected markets. Industries urged the government to ensure 
the interstate movement of the raw material for the food processing industry was not hindered. Although interstate travel has been banned, it does not apply to essentials, and in places like Maharashtra, the state police are yet to streamline the process, disrupting supply chains. During the lockdown period, the essential goods like the milk and newspaper supply chains are permissible to function.

\section{Impact on Demand \& Supply}

There is a stoppage or slowdown of the production of goods and services in India due to the effects of pandemic disease. It has disrupted the demand and supply chain across the country and, it can be seen that the tourism, hospitality, and aviation sectors are among the worst affected sectors. On the supply side, the impact of shutting down factories resulted in a delay in the supply of goods, which has affected a huge number of manufacturing sectors that source their intermediate and final product requirements. Some sectors like automobiles, pharmaceuticals, electronics, chemical products, etc. were impacted greatly. India is among the top 15 countries that have been affected most as a result of a manufacturing slowdown in China that is disrupting world trade. A survey by the Federation of Indian Chambers of Commerce \& Industry (FICCI) stated that the immediate impact of COVID-19 reveals that the direct impact on demand and supply of goods and services, and businesses also reduce the cash flows due to slowing economic activity which in turn is having an impact on all payments including to those for employees, interest rate, loan repayments, and taxes.

\section{Impacts on Tourism}

Tourism is a great revenue-earning sector in India. It has cultural and historical tourism, which attracts domestic and foreign inhabitants throughout the year. No wonder that a large number of confirmed COVID-19 cases in India include foreign tourists. But with visas being suspended and tourist fascinations being shut indefinitely, the whole tourism value chain, which includes hotels, restaurants, attractions, agents, and operators, is expected to face losses worth thousands of crores. Experts believed that the tourism industry is to take an enormous hit for the foreseeable future.

\section{Impact on Finance \& Economics}

Enactment of Goods and Service Tax (GST) makes the country running short, and the COVID -19 pandemic could make matters worse. With the impact of this lockdown, the Government of India is not in a rush to make any drastic changes in policy and offer tax relief as an extension in filings of GST for the financial year 2018-19 until June 30, 2020. India has also rearranged the introduction of mandatory e-invoicing until October 1, 2020. The financial market has practiced insecurity about the future course and consequences of COVID-19. The fall of Sensex in the second week of March 2020 reported and estimated Rs. 10 lakh crore of market cap. The investors resort to persistent selling amid rising cases of coronavirus. India is given an offer to assurance as much as 3 trillion rupees ( $\$ 39$ billion) of loans to small businesses as part of a plan to restart Asia's third-largest economy, which is revolving under the effect of a 40-day lockdown. The central bank offered 500 billion rupees credit line to mutual funds to avoid distress sale of assets and calm investor concerns on a lack of liquidity. A report says 100 million workers in mining, construction, manufacturing, and services sectors have been rendered jobless due to lockdown. Governments across the world are rushing to help small businesses.

\section{Government Actions to Mitigate the Impact of COVID -19}

- Assure to provide financial assistance for the poor in the unorganized sector by various state governments in India. The central government released 17,287 crores (US\$2.4 billion) to different states to help combat coronavirus.

- Union Cabinet approved the incentives worth ' 40995 crores for electronic manufacturing and announced a `15,000 crore (US\$2.1 billion) fund for the healthcare sector.

- The government announced the world's largest food security scheme for 80 crores $(800,000,000$ people) across the country.

- The Finance Minister announced several economic relief measures for the poor worth $` 170,000$ crores (US\$24 billion). 
- The Reserve Bank of India (RBI) made several announcements, including EMIs being put on hold for three months and reducing rates. Other measures introduced will make available a total 374,000 crore (US\$52 billion) to the country’s financial system.

- The Finance Minister made several announcements related to the economy, such as extending last dates for filing GST returns and income tax returns.

- To provide relief to taxpayers amid the COVID-19 crisis, the government will release `18,000 crores (US\$2.5 billion).

- The World Bank approved \$1 billion emergency financing for India to tackle coronavirus labeled 'India COVID-19 Emergency Response and Health Systems Preparedness Project.'

- The Asian Development Bank assured India of 15,800 crores (US\$2.2 billion) assistance in the COVID-19 outbreak fight.

\section{Conclusion}

India is one of the emerging economies which gives stiff competition in all spheres to the advanced countries in the world. The wave of COVID-19 smashed the entire economic activities in the country. The forty days lockdown almost brought the economy into a standstill position. The economic growth goes into the negative figure. Even though some measures made by the government through monetary, fiscal, and economic policy still, the economy's needs are not fulfilled desirably. A great financial loss occurs in all sectors that lead to an increase the government debts and deficit financing in the economy. The economists suggested that the revival from this recession takes another two years. A significant monetary and liquidity measures taken by the Reserve Bank and fiscal measures by the government would mitigate the adverse impact on domestic demand and help spur economic activity once normalcy is restored. Risks around the inflation projections appear balanced at this juncture, and the tentative outlook is benevolent relative to recent history. But COVID-19 hangs over the future, like a specter. Therefore an innovative measure needs to revive the economy. All resources should be used optimally without any wastages made. The appropriate technology needs to adapt to uplift the economic status of the country. The danger of the economy affects a lot than its health risks; therefore, the governments' concern needs to find the funds to fight COVID-19 and to keep the economy alive and augmentation.

\section{References}

COVID-19 to hurt IT Services Sector, Growth may fall to 3-5\% in FY21: ICRA, The Economic times, 2020, https://economictimes. indiatimes.com/tech/ites/covid-19-to-hurt-itservices-sector-growth-may-fall-to-3-5-infy21-icra/articleshow/75069492.cms

COVID-19 will reboot World into Virtual Reality: Kiran Mazumdar-Shaw, The Economic Times, 2020, https://economictimes.indiatimes.com/ news/company/corporate-trends/covid-19will-reboot-world-into-virtual-reality-kiranmazumdar-shaw/articleshow/75223254.cms

IMF projection for India's GDP growth highest in G-20, says RBI Governor Shaktikanta Das, India Today, https://www.indiatoday.in/ business/story/rbi-governor-shaktikanta-dasindian-economy-covid19-imf-projectiongdp-growth-1667889-2020-04-17.

Krueger, A.O. "The Missing Middle." Economic Reform in India: Challenges, Prospects, and lessons, edited by Nicholas C. Hope, et al, Cambridge University Press, 2013.

Ministry of Micro, Small and Medium Enterprises, Government of India, https://msme.gov.in.

Nicola, Maria. "The Socio-economic Implications of the Coronavirus Pandemic (COVID-19): A Review." International Journal of Surgery, vol. 78, 2020, pp. 185-193.

Parth, Kishore. "The Economic Cost of COVID-19: A Potential Pandemic Impact on Indian Economy." International Journal of Advanced Science and Technology, vol. 29, no. 6, 2020, pp. 2182-2192.

Rastogi, Siddhartha. The New Normal: Analysis of COVID-19 Impact on the Indian Economy, Making Smalltalk, 2020.

RBI Bulletin April 2020, vol. LXXIV, no. 4, 2020. Report of the Expert Committee on Micro, Small and Medium Enterprises, 2019. 
Shruti Agarwal. "Effect of COVID-19 on the Indian Suri, I.S. Impact of COVID-19 on Indian Economy Economy and Supply Chain." Preprints 2020, 2020050148. and Road Ahead for Corporate Sector, Business World, 2020.

\section{Author Details}

Dr. S. Jayaselvi, Assistant Professor, Department of Management Studies, Amrita College of Engineering and Technology, Nagercoil, Tamil Nadu, India, Email ID: selvi.jaya23@gmail.com. 